Tér és Társadalom $4 . \quad$ 1990-1: 121-128

\title{
KÖNYVJELZŐ
}

\section{HOMOKMÉGYI MŰHELYTANULMÁNYOK}

\section{Sorozatszerkesztố: Kiss József*}

Hazánk újkori történetének gazdasági, társadalmi válságai egyre-másra nemzeti önvizsgálatra késztettek, $s$ ez az önvizsgálat egy agrárországban szükségszerúen vezetett el a falu, a parasztság "betegségeihez", a diagnosztizálás igényéhez. A századforduló sokasodó agrárgondjai, a mezôgazdaság fejlôdése tradicionális útjainak lezáródása, az agrártúlnépesedés, a fokozódó kivándorlás is ösztönözte a Magyar Gazdaszövetség 1899-ben indított elsô hivatalos falukutatási programját. Sok forrásból táplál kozott, sok szálon futott a tanyakérdés vitája, s a progresszív polgári irányzatok (így pl. a Társadalomtudományi Társaság, a Huszadik Század köre) figyelme is a falu felé fordult. A két világháború közötti évek paraszti társadalmának általános válsága hívta életre a korszak egyik legnagyobb hatású szellemi mozgalmát, a népi írók tevékenységével, vezetô személyeivel is összefonódó falukutató mozgalmat. A szocialistának nevezett kényszerpálya zsákutcába torkollásáról, súlyosbodó gazdasági, kulturális, morális, társadalmi válságunkról a 70-es években terje- dố felismerés elôször szintén településpolitikai vitákban talált megszólalási lehetôséget, harci terepet. A vitázók rokonszenve az ideológiai, politikai, gazdasági megfontolásokból, a tervgazdálkodás jellegébốl fakadóan kisemmizett, megnyomorított falvak felé fordult, s így ismét természetszerũ, hogy Magyarország felfedezése legserényebben a falusi térségekben folyt; megszaporodtak a falukutató táborok, a faluszociográfiák, a falvakkal foglalkozó publicisztikai írások.

A közel száz évet átívelố falukutatás hullámai számos közös vonással bírnak. A vizsgálódásokat mindig is a válság érzete ösztönözte, s - akárcsak a közép-európai irodalom esetében - a beavatkozás igénye. A ,válság kezelésének" szándéka a hatalom részérôl is felmerült, létezett , hivatalos" falukutatás is, ám a falukutatás körül kialakult irodalom színezetét, jellegét az ellenzékiség, a protestálás adta meg, ez vezérelte megnyilatkozásait, javaslatait, akcióit. Ugyancsak közös vonása a 90 év falukutatásainak, hogy vezetổ mũfajává a szociográfia vált, $\mathrm{s}$ az ismeretek, a tény-

* Eddig megjelent tanulmányok: Kiss József: Egy falukutatás vázlata. - 1987. 128 old., Romsics Imre: A társadalmasított természet. — 1987, 87 old. , Csoba Judit: Két osztály határán. — 1987, 84 old. + mellékletek, Valuch Tibor: A hagyományos világ alkonya. - 1987, 59 old. (Terepfelverés után 1988, 144 old.) Valamennyi a ,Szociográfiai munkafüzetek" c. sorozatban jelent meg; sorozatszerkesztốk: Földiák András, Nyilas György, Tóth János. A szerkesztốk a következổ tanulmányok megjelenését tervezik: Fekete István: Homokmégy változó társadalma, Kiss József - Simon János (szerk.) A ,,megdermedt élet”" a hivatali dokumentumokban: 1950-1956. (Begyưjtés, adóztatás, mezôgazdasági termelés), Juhász Pál - Szelényi Iván: A városkutatástól a falukutatásig (Elōadások és beszélgetések szerkesztett szövege), Kiss József: A (paraszti) önkormányzat sorsa, 1945-1956. 
anyag, a bírálatok $\mathrm{s}$ a javaslatok jobbára futólagos terepszemlék nyomán kerültek a falukutatók birtokába, ill. fogalmazódtak meg.

A magyarországi falukutatás közel évszázados vonulatába sorolható a Népmưvelési Intézet és a Kossuth Lajos Tudományegyetem Szociológiai tanszéke által szervezett Falukutató Munkaközösség homokmégyi tevékenysége, azzal a rögtön hangsúlyozandó nem csekély különbséggel, hogy a több éven át megismételt táborozás során az "elsô áttekintést" meghaladóan a helyi társadalom sokoldalú vizsgálatára került sor, $\mathrm{s}$ a tapasztalások, a kutatások eredményei a recenziókban ismertetésre kerülố sorozatban napvilágot is láttak ill. látnak.

A Munkaközösség a Márkus István szervezte balástyai tábor szellemiségét ápolva a 80-as évek derekán rendezte homokmégyi táborozásait. Akkor, amikor a korábbi évekévtizedek településtervezésének és fejlesztésének, településpolitikájának, tanácsi igazgatásának vitája már javában folyt, javaslatok, ajánlások fogalmazódtak meg többnyire persze akár futólagos vizsgálódások eredményeinek is híján -, megfogalmazódott a hátrányos helyzetứ térségek, a megyehatár menti területek, az aprófalvak, tanyák panasza is, , utcára került" a népességmegtartó képesség némiképp álszent jelszava és így tovább. Ezért a Munkaközösség úgy döntött, ,,..., hogy nem a reformelvekkel, reformkoncepciókkal és vitákkal foglalkozunk majd, hanem annak a helyzetnek az esettanulmány érvényư leírásával, amely a jelenhez, mint történelmi problémához vezetett”. ,,Társadalomtörténeti vagy történeti szociológiai munkáinkban analítikusan és szigorúan történeti módon akarjuk leírni, dokumentálni azokat a falusi folyamatokat, amelyek azt bizonyítják, hogy miért és mennyire volt 'szükségszerư' a társadalom államosítása."

A történelemkutatói szemlélet s módszerek képezik az egyik általános jellemvonását a vizsgálatnak; pontosabban ,,... a történelem és a szociológia egybetartozásának a hite...". A falukutató tábor szükségszerüen kollektiv munkát kíván meg; nem véletlen, hogy a szervezốk szeme elốtt a Kemse-kutatás legendája, követendőnek vallott példája lebegett. A kollektív munka a homokmégyi táborban tudatos felkészüléssel párosult, $\mathrm{s}$ hozzájárult, hogy nem ,terepszemle", hanem mélyfúrás történt e Kalocsa környéki faluban. Mindezek eredményeként - az eddig megjelent füzetek ismeretében - remélhetô, hogy a magyarországi falutörténések egyik jól dokumentált színtere Homokmégy lesz, ez a kalocsai szállásokból 1898-ban önállósult, ma is több szállásból álló, mintegy hétezer lakosú község.

A Kiss Jozsef által írt füzet - Egy falukutatás vázlata - az, amit a címe ígér: a kutatás programja, módszertani megfontolásai, lefolyása, a vizsgálat tárgyának, Homokmégynek vázlatos bemutatása. Önálló tanulmányként is megállják helyüket a füzetben megjelent, a családi és rokoni kapcsolatrendszerek összehasonlító empirikus vizsgálatának módszertani kérdéseirôl írottak. A Szerzó egyetértóleg idézi Bartels-et: ,, Az emberi tevékenység területi szempontú', s a módszertani elveknél, a kutatási technikák kidolgozásánál érvényesíti felfogását: „A kezdetektốl hangsúlyoztuk ezeknek a kapcsolatoknak a területi jellegét is, általában a ,tér-elemnek" a fontosságát a társadalmi kapcsolatok megszületésében ill. megszüntetésében." E tanulmányt s a vizsgálati eredményeket a regionális kutatók figyelmébe is ajánljuk - a ,térpálya-analízis", az időföldrajz és a társadalmi kapcsolatrendszerek szociológiai analízise nehezen lehet meg egymás módszerei, eredményei nélkül.

Majd minden községmonográfiának része a természeti környezetnek, a környezet változásának - történeti földrajz -, a földrajzi kör- 
nyezet $\mathbf{s}$ a helyi társadalom kapcsolatának elemzése; s majd minden monográfia nehezen bírkózik e feladattal, vagy a szerzố(k) természettudományos ismereteinek hiánya, vagy a kellổ mélységú empirikus vizsgálatok szükségszerũ elmellôzése, vagy a kölcsönkapcsolatok elvi tisztázatlanságai, az ilyen fejezetek célkitûzéseinek bizonytalanságai miatt. Egyenetlen Romsics Imre munkája is, noha a sorozatszerkesztố bevezetôjében példamutató tömörséggel fogalmazta meg a természeti környezet $\mathbf{s}$ a társadalom (vagy praktice: a községmonográfiák) viszonyát: , ,, a történelem és a földrajz kapcsolatára építõ szemléleti és értelmezô keretben a 'földrajzi környezet' nem természeti kategória csupán, hanem erốsen és egyre visszafordíthatatlanabbul társadalmasított tér is." Ez a megállapítás adhatott volna útmutatást a kötet anyagának szelektálásában is. Különösen szükség lett volna erre az elemzést bevezetố geológiai fejezetben; az itt közölt adatok s a társadalom között vajmi kevés közvetlen kapcsolat mutatható ki. Nem válik e fejezet hasznára, hogy másodlagos forrásokból - a térséggel is foglalkozó könyvek, tanulmányok - ,,keresi vissza" a községre vonatkozó adatokat. Sokkal jobban sikerült a tér életében meghatározó szerepet betöltô vízrajzi viszonyok bemutatása, noha kérdés - amely rámutat a mũfaji jellegzetességekre is -: egy ilyen munkában szükség van-é a Duna nevének etimológiájára, vagy annak közlésére, hogy a mitológia szerint az Ister ,,... forrásánál laktak Apolló tisztelổi”. Így is egyértelmũen dokumentált a vízrajzi viszonyok és a társadalomfejlôdés, a gazdálkodás kapcsolata (mely itt, a kalocsai Sárréten különösen szoros volt), a társadalom hatalmas méretũ természetformáló munkája.

Sok ponton érintkezik Csoba Judit (Két osztály határán) és Valuch Tibor (A hagyományos világ alkonya) tanulmánya; olvasásuk során a Homokmégyet alkotó szállások társadal- mának, egy földrajzi, etnikai zártságban élô, a tájegység katolikus sváb és református magyar településeihez képest gazdasági elmaradottsággal jellemezhetô, tradicionális praszttársadalomnak a felbomlási folyamata bontakozik ki.

E folyamat statisztikailag leginkább megragadható összetevớje a foglalkozásváltás (foglalkozási átrétegzôdés) és - a helyi munkaalkalmak szúkössége következtében - az ingázóvá-válás. E folyamat statisztikai jellemzôirốl meglehetốsen sokat tudunk, Csoba Judit célja azonban nem az ingázás, hanem az ingázó társadalom, az ingázó életforma vizsgálata. A tanulmány e célkitûzést magas színvonalon valósítja meg; vizsgálódásai nyomán nemcsak Homokmégy ingázóiról, hanem az ingázó társadalom és életmód kialakulásának feltételeirốl, folyamatáról is olyan ismeretekhez jutunk, amelyek az ingázóvá-válás, az ingázás és a társadalom kölcsönkapcsolatának általános folyamatáról, jellegzetességeirôl rendelkezésünkre álló ismereteket is bôvítik. A kutatások nyomán a mennyiségi ismérvekkel jellemzett egységes folyamat - a kiingázók számának, arányának változása, ingázási távolság stb. - jól tagolható, eltéró jellegũ szakaszokra bontható, s kibontakozik a község társadalma és az ingázás kölcsönkapcsolatának sokrétüsége. A , hôskor" a két világháború közötti évekre esik. Ekkor vált - községhatáron túl vállalt munka egyedi esetébốl életformává vagy legalábbis az élet rendszeresen visszatérố mozzanatává a munka utáni vándorlás. A homokmégyiek jobbára a környezô nagybirtokok napszámosai, részesaratói ill. távolabbra is eljáró kubikusok. ,,Azokban az 50-es években" megszaporodik a távoli munkahelyekre eljárók száma, ám ezek a ,,vállalkozások" szándék szerint ideiglenesek, gyakran a mezôgazdasági holtszezonra korlátozódnak; a mezõgazdaságból való menekülés még nem tömeges és nem végleges. 
Megfigyelhetổ, hogy az évek során egyre tehetốsebb rétegre ,,kerül sor”, már nemcsak a nincstelenek, hanem a kis- és középparasztok is ipari munkára kényszerülnek. A homokmégyiek a 60-as években kezdtek tömegesen ,,a lábukkal szavazni". A már korábban is eljárók számára nyilvánvalóvá vált, hogy foglalkozásváltásuk végleges, a paraszti életforma lezárult elốttük, a szervezổdổ termelôszövetkezetek sem tartanak rájuk igényt. Választás elé a tehetốsebb rétegek kerültek; többségük elköltözött. Kalocsa ipari fejlesztése lehetổvé tette a hatvanas évek végétổ a napi munkábajárás tömegesülését is. De ez sem mérsékli számottevôen az elvándorlást - Homokmégy , demográfiai potenciálja" látványosan csökken.
Az utolsó etap: a nôk is elindulnak a város felé munkát vállalni. Az ingázók típusainak kubikus-utódok, ,mélyrổl jövổ””, kétlaki vállalkozók, egyenruhás bejárók stb. - fölvázolása jól összegzi e folyamatok végeredményét.

Valuch Tibor tanulmánya a hagyományos paraszti társadalom erổszakos kollektivizálási hullámok által gyorsított bomlásának látlelete; precíz leírás, ám kevés új momentumot tud hozzátenni a "téeszesítés" szomorú történetéhez.

A kutatás ismertetett eredményei felkeltették a recenzorok érdeklódését az ígért további kötetek iránt.

V. M. M. - byp - R. L.

Felhivjuk tisztelt Olvasóink figyelmét, hogy a

Tér és Társadalom

Budapesten az alábbi hírlapüzletekben kapható:

Váci utca 10.

Szabad sajtó út 6 .

Felszabadulás tér 4.

Petőfi Sándor utca 17. Párizsi udvar (hírlapüzlet)

Szent István krt. 25.

Bem utca 9.

Lenin krt. 17.

Baross téri aluljáró (hirlapüzlet)

Marx téri aluljáró (hirlapüzlet)

Déli pu. aluljáró (hirlapüzlet)

Rákosfalva park $3 / \mathrm{c}$.

Hegedủs Gyula utca 24.

Bajcsy-Zsilinszky út 76. (közlönybolt) 